\author{
Marta Rojewska \\ Uniwersytet Warszawski
}

DOI: $10.19195 / 2450-274 X .2 .9$

\title{
Federacja europejska - projekt polityczny czy utopia?
}

Abstrakt: W przeszłości, w debacie toczącej się w latach czterdziestych i pięćdziesiątych, która doprowadziła do powstania Europejskiej Wspólnoty Węgla i Stali, Europejskiej Wspólnoty Gospodarczej oraz Europejskiej Wspólnoty Energii Atomowej, różne koncepcje i postulaty składały się na nurt koncepcji wzywających do budowania jedności i pokoju w Europie w duchu federalnym. Stanowiły one jedną z dominujących inicjatyw, będąc jednym z najważniejszych konceptów teoretycznych leżących u podstaw projektu integracyjnego. Obecnie, w obliczu kryzysów targających Unią Europejską (kryzys przywództwa, kryzys finansowy, kryzys strukturalny), znów intensywnie mówi się o federacji jako możliwym finalité politique. W artykule podjęto próbę odpowiedzi na pytanie czy postulaty federalistów stanowią realny projekt polityczny czy utopię, która pozostanie niezrealizowana, dokonując w tym celu porównania koncepcji tzw. etapu klasycznego oraz wspólczesnych pod kątem argumentów za utworzeniem federacji europejskiej, metod i efektów.

Słowa kluczowe: federalizm, federacja europejska, federalne koncepcje integracji europejskiej, federalne elementy Unii Europejskiej, federalizm ewolucyjny, federalizm rewolucyjny

\section{The European Federation - a political project or utopia?}

Abstract: In the past, in the discourse (in the 1940s and 1950s) which led to the creation of the European Coal and Steel Community, the European Economic Community and the European Atomic Energy Community, different concepts and demands created the set of concepts calling to building the unity and the peace in Europe in the spirit of federalism. These concepts were the dominant and most important theory underlying the integration project. Now, in the face of crises in the European Union (leadership crisis, financial crisis, structural crisis), the discussion on the idea of federation as possible finalité politique is gaining popularity again. This article attempts to answer the question whether federalist's demands are a viable political project or utopia, which remain unrealized. For this aim, the author made a comparison between classical and contemporary federal concepts taking into consideration the arguments for the creation of the European federation, methods and effects.

Keywords: federalism, the European Federation, federal concepts of European integration, federal elements of the European Union, evolutionary federalism, revolutionary federalism 
Jak długo w Paneuropę wierzą tysiące - jest ona utopią, kiedy uwierzą miliony — stanie się programem politycznym, skoro tylko uwierzy w nią sto milionów - będzie to jej urzeczywistnieniem.

\section{Współczesne koncepcje federacji europejskiej na tle rozwoju federalizmu w Europie}

„Dla wielu obserwatorów bieżącej politycznej debaty o przyszłości Europy, opublikowanie konstytucyjnego projektu federalnej Europy w tym momencie wydaje się być wysoce ambitne w najlepszym przypadku - albo nawet nierealistyczne w najgorszym" ${ }^{2}$ - tymi słowy Thomas Fischer i Joachim Fritz-Vannahme rozpoczęli posłowie do „A Fundamental Law of the European Union”, projektu federalnej konstytucji dla Unii Europejskiej, zaprezentowanej w 2013 r. przez Grupę Spinellego (The Spinelli Group). Niewątpliwie federalne koncepcje integracji europejskiej należą do najstarszych i najbardziej rozbudowanych sposobów myślenia o kształcie zintegrowanej Europy ${ }^{3}$. Współcześnie jednak pozycja tego nurtu w debacie o przyszłości Unii Europejskiej jest dość specyficzna - mimo powszechnego uznania dla jego dorobku, „słowo na F” budzi niepokój. W efekcie pojawia się pytanie o to, czy propozycję utworzenia federacji europejskiej uznaje się jeszcze za realny projekt polityczny, czy jednak należy go zakwalifikować jako utopię. W kontekście tego głównego pytania badawczego należy również pochylić się nad prezentowanymi współcześnie pomysłami — nad tym, jakie niosą rozwiązania, jak motywują swoją słuszność; jak traktowana jest federacja — jako metoda integracji, środek procesów integracyjnych, a może koncepcja już wdrożona w życie? W celu uzyskania odpowiedzi na powyższe pytania badawcze zastosowano przede wszystkim metody historyczną oraz komparatywną.

Warto na początek odnotować kilka kwestii dotyczących rozwoju federalizmu w pierwszej połowie XX w., które później będą mieć znaczenie dla próby odpowiedzi na główne pytanie niniejszego artykułu. Pierwsze koncepcje federalnej Europy pojawiały się już w XIV w., natomiast początek tzw. etapu klasycznego przypada na lata dwudzieste XX w. Po zakończeniu I wojny światowej Richard Coudenhove-Kalergii, Aristide Briand, Édouard Herriot, C.F. Heerfordt przedstawili swoje plany integracji europejskiej w duchu federalnym jako jedyny sposób uniknięcia kolejnego wielkiego konfliktu europejskiego. Na bazie tych wizji w czasie

${ }^{1}$ R. Coudenhove-Kalergi, Pan-Europa, Racibórz 2005, s. 11.

2 T. Fischer, J. Fritz-Vannahme, Last Words, [w:] The Spinelli Group, Bertelsmann Stiftung, A Fundamental Law of the European Union, Gütersloh 2013, s. 305.

${ }^{3}$ W. Bokajło, Federacyjne projekty ustrojowe dla Wspólnoty Europejskiej, [w:] Polska w procesie integracji europejskiej. Dekada doświadczeń (2004-2014), red. K.A. Wojtaszczyk, M. Mizerska-Wrotkowska, W. Jakubowski, Warszawa 2014, s. 85. 
II wojny światowej i po jej zakończeniu wyrósł potężny ruch będący rzecznikiem utworzenia europejskiej federacji. Działalność antyfaszystowskich ruchów oporu w trakcie wojny oraz Altiero Spinellego, Winstona Churchilla, Jeana Monneta i Ruchu Europejskiego stworzyły podwaliny dzisiejszego myślenia o federalizmie. $\mathrm{W}$ ramach tych postulatów można zauważyć pewną dychotomię ${ }^{4} \mathrm{~W}$ sposobie dążenia do federacyjnego celu. Pierwszy nurt federalizmu to tzw. model konstytuanty (inaczej rewolucyjny), który zakłada, iż utworzenie federacji europejskiej nastąpi na skutek zwołania ogólnoeuropejskiego gremium przedstawicielskiego (zgromadzenia konstytucyjnego, konwentu), które opracuje i uchwali konstytucję nowego bytu politycznego. Zwołanie konstytuanty miało być albo decyzją władz europejskich państw, albo oddolnym ruchem społecznym wywierającym presję na rządy. Najważniejszym reprezentantem tego nurtu był Altiero Spinelli. Na drugim końcu skali znalazł się Jean Monnet, którego federalizm ewolucyjny zakładał rozpoczęcie integracji w wąskich obszarach ekonomicznych i stopniowe dochodzenie do federacji europejskiej (jak określa to Michael Burgess, jest to „federalizm na raty”). J. Monnet nie określał dokładnego końca tego procesu - proces spill-over miał doprowadzić do stopniowego zbliżania narodów europejskich, budowy zaufania i powiązań między nimi, etapami obejmując coraz to nowe dziedziny ${ }^{5}$.

Koniec okresu największej świetności federalnych koncepcji integracji europejskiej to upadek inicjatywy utworzenia Europejskiej Wspólnoty Obronnej i Europejskiej Wspólnoty Politycznej. Oba projekty zawierały wyraźne nawiązania do rozwiązań federalnych - przede wszystkim samo utworzenie europejskiej armii (jako niezależnych sił zbrojnych, a nie sumy narodowych jednostek), kształt zgromadzenia parlamentarnego (dwuizbowość w oparciu o wybory bezpośrednie oraz reprezentację państw członkowskich), unia obywateli („My, Narody”), a nie państw. Rządy Charlesa de Gaulle’a we Francji, przeciwnika ponadnarodowości i przekazywania kompetencji na wspólnotowy poziom oraz odbudowa zaufania obywateli do instytucji państwowych na dłuższy czas skutecznie zablokowały próby dążenia do stworzenia federacji europejskiej ${ }^{6}$.

Powrót do myślenia o przyszłości Europy w duchu federalnym to początek lat osiemdziesiątych, kiedy rozpoczął się okres wchodzenia na wyższy poziom inte-

${ }^{4}$ Poza tym rozróżnieniem znajduje się federalizm integralny, który związany jest $\mathrm{z}$ filozofią personalistyczną. Ten rodzaj federalizmu nawoływał do przywrócenia godności osobie ludzkiej w globalnym, kapitalistycznym świecie. Jednostka miała na nowo stać się odpowiedzialnym członkiem społeczeństwa, biorącym udział w procesach decyzyjnych na każdym poziomie — od przedsiębiorstwa po poziom ogólnoeuropejski. Przedstawiciele tego nurtu to m.in. Jacques Maritain, Eduard Mounier, Denis de Roquemont. Zdaniem Michaela Burgessa był to federalizm utopijny. P.J. Borkowski, Polityczne teorie integracji międzynarodowej, Warszawa 2007, s. 62-63; M. Burgess, Federalism, [w:] European Integration Theory, red. A. Wiener, T. Diez, wyd. 2, New York-Oxford 2009, s. 32-33.

${ }^{5}$ M. Burgess, Federalism, s. 32, 38.

${ }^{6}$ A. Jaskulski, Federalizm europejski początków integracji europejskiej i doby kryzysu, „Rocznik Integracji Europejskiej" 2012, nr 6, s. 222-223. 
gracji europejskiej, a więc czas prac nad powołaniem do życia Unii Europejskiej. Uznaje się niekiedy, że początek tego okresu wyznacza raport Tindemansa, choć niewątpliwie najważniejszym wydarzeniem tego okresu jest przyjęcie przez Parlament Europejski w 1984 r. Projektu Traktatu ustanawiającego Unię Europejską, stworzonego przez „Klub Krokodyla” - grupę deputowanych do PE pod przewodnictwem Altiero Spinellego ${ }^{7}$.

Od początku XXI w. mamy do czynienia $z$,trzecią falą” federalnych koncepcji integracji europejskiej. Za jej początek należy uznać słynne przemówienie Joshki Fischera na Uniwersytecie Humboldta 12 maja 2000 r. Ówczesny minister spraw zagranicznych Niemiec wezwał w nim do utworzenia federacji europejskiej opartej na „nowej konstytucji dla Europy”. Federacja miałaby posiadać wspólny rząd i prezydenta jako władzę wykonawczą oraz dwuizbowy parlament stanowiący władzę ustawodawczą. Konstytucja miała określać podział suwerenności (division of sovereignty, die Souveränitätsteilung $)^{8}$ między poziomem europejskim i narodowym. Pierwsza izba Parlamentu Europejskiego byłaby złożona z przedstawicieli społeczeństwa europejskiego wybieranych spośród deputowanych parlamentów narodowych, druga izba $z$ senatorów wyłonionych w bezpośrednich wyborach (zgodnie z modelem amerykańskim) lub przedstawicieli rządów państw członkowskich. Co ważne projekt Fischera zakładał zawarcie traktatu konstytuującego federację europejską przez „środek ciężkości”, czyli grupę państw zdecydowanych na dokończenie procesu integracji'. Pomysł ten nie był nowy i wpisywał się w dość popularną od połowy lat dziewięćdziesiątych narrację o integracji „wielu prędkości”, „zmiennej geometrii” lub o „twardym rdzeniu integracji”, która zakładała, że nie wszystkie państwa członkowskie Unii Europejskiej zdecydują się na zawiązanie federacji ${ }^{10}$.

W 2011 r. Andrew Duff w książce Federacja już! przedstawił postulaty przekształcenia Unii Europejskiej w kierunku federacji, do czego niezbędne byłyby reformy systemu wyborczego, stworzenie unii fiskalnej, zmiany w zasadach budżetowych, stworzenie federalnego rządu gospodarczego. Zdaniem tego polityka aktualny kryzys w UE jest właśnie efektem tego, że projekt federalny nie został jak dotąd zrealizowany, a jeśli nawet podejmowano takie próby, to nie były one wystarczająco skuteczne. Przyszły kształt europejskiej federacji według Duffa to

7 Por. M. Burgess, Federalism and European Union: the Building of Europe, 1950-2000, London-New York 2000, s. 101, 139-151.

${ }^{8}$ W nauce polskiej uznaje się niepodzielność suwerenności, a mówi się jedynie o podziale kompetencji lub atrybutów z niej wynikających.

${ }^{9}$ J. Fischer, From Confederacy to Federation - Thoughts on the finality of European integration, [w:] What Kind of Constitution for What Kind of Polity? Response to Joschka Fischer, red. Ch. Joerges, Y. Mény, J.H.H. Weiler, Florence-Cambridge 2000, s. 25-27.

${ }^{10}$ Por. W. Schäuble, K. Lamers, Überlegungen zur europäischen Politik, 1.09.1994, oficjalna strona internetowa: CDU/CSU, https://www.cducsu.de/upload/schaeublelamers94.pdf (dostęp: 14 stycznia 2016). 
wielopoziomowa demokracja parlamentarna oparta na spisanej konstytucji, wyraźnym podziale kompetencji i zasadzie pomocniczości ${ }^{11}$.

Rok później José Manuel Barroso wygłosił w Parlamencie „Orędzie o stanie Unii”, w którym wezwał do utworzenia federacji państw narodowych. Mówiąc o kryzysie, z jakim boryka się Unia, wskazał na potrzebę natychmiastowego podjęcia decyzji o nowym kierunku integracji — opartym na solidarności i lojalności, ale przede wszystkim na uświadomionej wspólnocie celów, interesów i wartości. „Przełomowy pakt na rzecz Europy” zakładał po pierwsze pogłębienie unii gospodarczej - zakończenie budowy jednolitego rynku, wdrożenie Paktu na rzecz wzrostu gospodarczego i zatrudnienia, utworzenie unii bankowej i fiskalnej, stworzenie podstaw unii budżetowej; po drugie wzmocnienie unii politycznej - umocnienie statusu ogólnoeuropejskich partii politycznych, stworzenie mechanizmu wyboru przewodniczącego Komisji Europejskiej spośród kandydatów zaproponowanych przez europejskie partie, ustanowienie Prokuratury Europejskiej. Jak stwierdził J.M. Barroso: „Pogłębiona i autentyczna unia gospodarcza i walutowa, unia polityczna o spójnej polityce zagranicznej i obronnej oznacza, te zamierzenia oznaczają, że obecna Unia Europejska musi ewoluować. Nie bójmy się tego powiedzieć: będziemy musieli dążyć w kierunku federacji państw narodowych", a w tym celu konieczne będzie uchwalenie nowego traktatu ${ }^{12}$.

$\mathrm{W}$ ostatnich latach kilku innych znaczących polityków również wzywało do federalizacji Unii Europejskiej. W wystąpieniu na forum Niemieckiego Towarzystwa Polityki Zagranicznej (Berlin, 28 listopada 2011 r.) Radosław Sikorski stwierdził, iż „stoimy [w Unii Europejskiej - M.R.] przed wyborem, czy chcemy być prawdziwą federacją, czy też nie. Jeżeli ponowna nacjonalizacja lub rozpad są nie do zaakceptowania, pozostaje nam tylko jedna możliwość: sprawienie, by Europą w końcu można było rządzić, a co za tym idzie, doprowadzenie z czasem do Europy bardziej wiarygodnej”. Droga do europejskiej federacji według polskiego ministra spraw zagranicznych oznaczała wzmocnienie instytucji ponadnarodowych - przede wszystkim Europejskiego Banku Centralnego, Parlamentu Europejskiego i Komisji Europejskiej, utworzenie nowego, wyłanianego w wyborach bezpośrednich, unijnego urzędu z połączenia stanowisk przewodniczących Rady Europejskiej i Komisji Europejskiej, ale również konieczność stworzenia katalogu spraw zastrzeżonych do wyłącznej kompetencji państw członkowskich ${ }^{13}$. W styczniu 2012 r. Angela Merkel w wywiadzie dla prasy europejskiej powiedziała: „Moją wizją jest unia polityczna [...] Więcej kompetencji oddamy Komisji Europejskiej,

${ }^{11}$ A. Duff, Federacja już!, przeł. W. Piecyk, Warszawa 2011, s. 6, 8, 9, 11-28.

12 J.M. Barroso, Przewodniczący Komisji Europejskiej, Orędzie o stanie Unii w 2012 r., Sesja plenarna Parlamentu Europejskiego, Strasburg 12 września 2012 r., http://europa.eu/rapid/press-release_SPEECH-12-596_pl.htm (dostęp: 14 stycznia 2016).

${ }_{13}$ Przemówienie ministra Radosława Sikorskiego Polska i przyszłość Unii Europejskiej na forum Niemieckiego Towarzystwa Polityki Zagranicznej, Berlin, 28 listopada 2011 r., https://www. msz.gov.pl/resource/c2a33d88-7b8d-4fa5-8680-a67a4b2b38af:JCR (dostęp: 14 stycznia 2016). 
która będzie jak europejski rząd. Do tego silny Parlament Europejski. Niejako drugą izbę tworzyć będzie Rada UE z szefami rządów. I w końcu mamy Europejski Trybunał Sprawiedliwości jako Sąd Najwyższy"14. W 2014 r. podczas konferencji „The State of the Union”"15, w przeddzien rozpoczęcia włoskiej Prezydencji w UE, premier Włoch Matteo Renzi zapowiedział, że jednym z priorytetów włoskiego rządu w czasie nadchodzącego półrocza będzie zbliżanie Unii Europejskiej do utworzenia Stanów Zjednoczonych Europy ${ }^{16}$.

Guy Verhofstadt, Daniel Cohn-Bendit, Sylvie Goulard, Isabelle Durant, Andrew Duff i Jo Leinen we wrześniu 2010 r. założyli Grupę Spinellego, której celem jest działalność na rzecz pogłębienia procesów integracji w duchu federalnym. Tworzy ją sieć obywateli, polityków, naukowców i pisarzy, a dodatkowo w Parlamencie Europejskim zrzesza ona 110 deputowanych w ponadfrakcyjnej grupie parlamentarnej ${ }^{17}$. Grupa, wzorem swojego patrona Altiero Spinellego, opublikowała w 2013 r. projekt traktatu dla Unii Europejskiej, który jako reforma obecnie obowiązujących traktatów (w brzmieniu Traktatu z Lizbony) ma być krokiem w kierunku unii federalnej ${ }^{18}$. Podstawowe zmiany to przekształcenie Komisji Europejskiej w demokratyczny, konstytucyjny rząd, włączenie Karty Praw Podstawowych jako części II traktatu, ograniczenie głosowania w oparciu o zasadę jednomyślności do kilku wyjątkowych przypadków (np. decyzji o przyjęciu nowego państwa), zniesienie ograniczeń w jurysdykcji Trybunału Sprawiedliwości Unii Europejskiej, uzależnienie zmiany traktatu i przyjęcia nowego państwa od zgody Parlamentu Europejskiego, nadanie Radzie i Parlamentowi Europejskiemu roli legislatury ${ }^{19}$.

Jak podkreśla M. Burgess, obecne postulaty federalistów koncentrują się przede wszystkim wokół rozszerzenia zakresu spraw podlegających głosowaniu większościowemu w Radzie i zwykłej procedurze prawodawczej, zwiększenia odpowiedzial-

${ }^{14}$ Cyt. za S. Parzymies, Między Europa ojczyzn a federacja: fałszywy dylemat europejskiej integracji, wystąpienie na Pierwszym Sympozjum im. Ministra Krzysztofa Skubiszewskiego poświęcone polityce zagranicznej RP, zorganizowanym przez Instytut Stosunków Międzynarodowych Uniwersytetu Warszawskiego oraz przez Fundację imienia Krzysztofa Skubiszewskiego, Uniwersytet Warszawski, 21 lutego $2012 \mathrm{r}$.

15 „The State of the Union” jest konferencją poświęconą refleksji nad przyszłością Unii Europejskiej, organizowaną co roku we Florencji przez European University Institute. Biorą w niej udział politycy najwyższego szczebla, przedstawiciele środowiska akademickiego i społeczeństwa obywatelskiego. W 2014 r. wzięli w niej udział José Manuel Barroso, Karel De Gucht, Jean-Claude Junker, Federica Mogherini, Mario Monti, Danuta Hübner, Giuliano Amato, Romano Prodi, Martin Schulz, Guy Verhofstadt, J.H.H. Weiler i wielu innych. Oficjalna strona internetowa „The State of the Union", https://stateoftheunion.eui.eu/ (dostęp: 15 stycznia 2016).

${ }^{16} \mathrm{M}$. Bonucci, Italian PM vows to push for United States of Europe during presidency, EurActiv. com 09.05.2014, http://www.euractiv.com/sections/eu-elections-2014/italian-pm-vows-push-united-states-europe-during-presidency-302048 (dostęp: 15 stycznia 2016).

${ }_{17}$ About us: The Spinelli Group in a few words, oficjalna strona internetowa The Spinelli Group, http://www.spinelligroup.eu/about-us (dostęp: 15 stycznia 2016).

${ }_{18}$ The Spinelli Group, Bertelsmann Stiftung, A Fundamental Law..., s. 5.

19 Ibidem. 
ności i przejrzystości procesów decyzyjnych w Radzie, wyboru przewodniczącego Komisji Europejskiej oraz możliwości wezwania do dymisji poszczególnych komisarzy przez Parlament Europejski, zwiększenia unijnego budżetu oraz rozszerzenia władzy budżetowej Parlamentu Europejskiego, zwiększenia udziału instytucji ponadnarodowych w Wspólnej Polityce Bezpieczeństwa i Obrony ${ }^{20}$. Do tej listy należałoby dodać kwestie dwuizbowości Parlamentu Europejskiego, doprecyzowanie podziału kompetencji między poziomami władzy, przyjęcie aktu konstytucyjnego, wykształcenie europejskiej tożsamości.

\section{Federacja europejska - cel i metoda integracji europejskiej}

Jeśli przyjąć założenie, że kompleksowa koncepcja integracji europejskiej, zwłaszcza jeśli ma pretendować do miana projektu politycznego, powinna podawać argumenty świadczące na rzecz rozpoczęcia procesu integracji, wyjaśniać metody jakimi ta integracja powinna zachodzić oraz określać jej ostateczny cel, czyli finalité politique, to warto w tym miejscu podjąć analizę federalizmu pod tym właśnie kątem.

Między koncepcjami etapu klasycznego i współczesnymi widać kilka zasadniczych różnic. O ile sam rdzeń, czyli założenia dotyczące konstrukcji przyszłej federacji (coś co można by w skrócie określić mianem zasady federalnej), w gruncie rzeczy nie uległy zmianie, o tyle zmieniła się towarzysząca temu narracja, rozumiana jako przesłanki do dokonania zmian, ale i określenie ich ostatecznego celu. Jak wskazuje Adam Jaskulski „o ile w przypadku lat 40-tych i 50-tych XX wieku można było mówić o spójnych projektach, których jasno określonym celem było zbudowanie państwa federalnego, o tyle obecnie mówimy przede wszystkim o rozwiązaniach, które mają skutkować federalizacją UE [...] bez określenia ostatecznego celu, jaki ma być ich efektem" ${ }^{21}$. Druga zmiana dotyczy motywacji rozpoczęcia procesu federalizacji.

Federalizm był tą koncepcją integracji europejskiej, która najdobitniej wskazywała na potrzebę zerwania $\mathrm{z}$ porządkiem europejskim, tworzonym przez suwerenne państwa narodowe. Ten postulat był efektem dwóch wojen światowych, które skutecznie naruszyły wiarę Europejczyków w zdolność instytucji państwa narodowego do zapewnienia pokoju i bezpieczeństwa swoim obywatelom ${ }^{22}$. W kontekście słabnącej roli państw narodowych Marek Cichocki wskazuje, iż u podłoża integracji europejskiej leży nie tyle katastrofa wojen światowych, które były tylko kulminacją dłuższego procesu, ile sięgający dalej w przeszłość proces. Od połowy XIX w. Europa borykała się bowiem z problemem słabnącej pozycji

\footnotetext{
20 M. Burgess, Federalism, s. 41.

21 A. Jaskulski, op. cit., s. 230.

22 P.J. Borkowski, Polityczne teorie..., s. 57.
} 
w świecie i niezdolnością do utrzymania równowagi sił na samym kontynencie. "Niemoc nowożytnych państw” wywołała poszukiwania nowej drogi, nowej formuły politycznej, która byłaby w stanie zaradzić tendencji spychania Europy na margines stosunków międzynarodowych ${ }^{23}$. W obu przypadkach przywrócenie wiary w pewną i obiecującą przyszłość Europy miała zapewnić właśnie federacja europejska. Trzeba jednak podkreślić, że obawa przed kolejną bratobójczą wojną była narracją, która mogła przekonać zwykłych obywateli, natomiast argumenty przedstawione przez M. Cichockiego odnoszą się raczej do motywacji, jakie mogły kierować politykami przy podjęciu decyzji o rozpoczęciu projektu integracyjnego (choć niekoniecznie w duchu federalnym). Co ciekawe, właśnie o słabnącej roli Europy mówił José Manuel Barroso w orędziu z 2012 r.: „w XXI wieku nawet największe kraje europejskie mogą stać się mało znaczące wśród światowych gigantów, takich jak Stany Zjednoczone czy Chiny. [...] Europa ma wszystkie potrzebne atuty. Jest ich dziś znacznie więcej, niż miały do dyspozycji poprzednie pokolenia borykające się z podobnymi, a nawet trudniejszymi wyzwaniami. Musimy jednak podjąć stosowne działania i wykorzystać te walory wspólnie"24.

Zdaniem niektórych badaczy postulat zerwania z państwem narodowym jest wciąż aktualny - obecny kryzys gospodarczy (i będący jego następstwem kryzys polityczny) spowodował powrót do federalnego myślenia o przyszłości Europy właśnie dlatego, że wiara w państwo narodowe ponownie została zachwiana, tym razem na skutek bezradności wobec lekkomyślnych działań sektora finansowego $^{25}$. Pogląd ten jest jednak o tyle wątpliwy, że kryzys projektu integracyjnego, nie pierwszy zresztą i bynajmniej nie ostatni, doprowadzić może raczej do umocnienia pozycji państwa narodowego ${ }^{26}$, poza tym przywiązanie obywateli do państwa obecnie jest zbyt silne, a siła eurosceptycyzmu, jaki zawładnął debatą publiczną, zbyt mocno podważa zaufanie do procesów integracyjnych, by na tym etapie stały się one istotną kontrpropozycją dla państw. Przeczą temu również sami federaliści - w profederalistycznej narracji widać obecnie zupełnie inny trend. Pojawia się w niej bowiem tendencja do podejmowania próby połączenia wizji federalnej UE i dalszego trwania państwa narodowego. Głównym przykładem jest tu wspomniana wcześniej koncepcja J.M. Barroso. Tendencja ta jest niewątpliwie próbą połączenia pewnego status quo z postulowanym stanem idealnym.

Proces integracji europejskiej pokazał dobitnie, że w pełni możliwa jest pokojowa koegzystencja państw narodowych. Napięcia i spory między państwami nie zostały oczywiście całkowicie wyeliminowane, ale nie dotyczą one już kwestii fundamentalnych (takich jak przebieg granic czy ideologie), a są raczej naturalnym elementem procesów decyzyjnych i demokratycznego dyskursu. W efekcie

${ }^{23}$ M.A. Cichocki, Zapomniana Europa, „Teologia Polityczna” 2006/2007, nr 4, s. 229.

${ }^{24}$ J.M. Barroso, Przewodniczący Komisji Europejskiej, Orędzie o stanie Unii w 2012 r.

25 A. Jaskulski, op. cit., s. 221.

${ }^{26}$ O możliwości zaistnienia takiej tendencji świadczyć może chociażby obecnie tocząca się dyskusja o przyszłości strefy Schengen w obliczu kryzysu migracyjnego w 2015 i 2016 r. 
zdewaluował się kluczowy argument federalistów, mówiący o konieczności zerwania z państwem narodowym w celu tworzenia lepszej, federalnej przyszłości Europy $-\mathrm{w}$ jego miejsce przywołano argumenty funkcjonalistyczne, mówiące o przywracaniu sterowności i efektywności projektu europejskiego, który w obliczu tak dużej liczby członków i tak wielu obszarów działalności boryka się z poważnym kryzysem ${ }^{27}$.

John McCormick wskazuje, że o ile w 1946 r., gdy utworzono Unię Europejskich Federalistów, jedno z największych europejskich ugrupowań prointegracyjnych, szanse utworzenia federacji europejskiej były jeszcze stosunkowo duże, o tyle w 1948 r., gdy w Hadze obradował słynny Kongres Europejski, państwo narodowe zostało już odbudowane i ta szansa przeminęła ${ }^{28}$. To stwierdzenie prowadzić może do innego wniosku - na tym etapie decyzja o budowie europejskiej federacji w duchu nurtu rewolucyjnego była już niemożliwa, a federalizacja Europy mogła odbywać się tylko poprzez wprowadzanie elementów federalnych „tylnymi drzwiami”, pojedynczo, bez akcentowania ich federalności, a jedynie przy wskazywaniu ich użyteczności.

Kolejną kwestią istotną w kontekście głównego pytania, jest problem rozumienia i postrzegania samego federalizmu. W debacie nad przyszłością integracji europejskiej federalizm traktowany jest niekiedy jak relikt przeszłości lub niebezpieczna koncepcja stopienia państw narodowych i ich różnorodności w jedno bezosobowe wszechwładne „superpaństwo”. Narzucone przez nurt prawniczy rozumienie federacji jako państwa federalnego powoduje, że dyskusję o federalizacji Unii Europejskiej z gruntu uznaje się za utopijną — skoro bowiem UE zaprojektowana została jako organizacja międzynarodowa, to wykluczone jest zarówno na poziomie formalno-prawnym, jak i na poziomie woli politycznej przekształcenie jej w kierunku państwowości ${ }^{29}$. Gdy jednak przyjąć odmienną definicję federalizmu, wynikającą raczej $\mathrm{z}$ analizy pojawiających się $\mathrm{w}$ debacie koncepcji niż z doktryny, może się okazać, że federalizm wciąż pozostaje realnym projektem politycznym. Definicja taka zakłada, iż federacja jako finalité politique w kontekście europejskim jest formą organizacji wspólnoty politycznej, w której zgodnie z zasadami subsydiarności oraz rozdziału kompetencji zachodzi podział władzy między różne poziomy; ponadto wspólnota taka wyposażona jest w prawne mechanizmy rozwiązywania konfliktów i pewną dozę autonomii oraz wymaga od jednostek partycypacji w jej funkcjonowaniu ${ }^{30}$.

${ }^{27}$ A. Jaskulski, op. cit., s. 225.

${ }^{28}$ J. McCormick, European Union Politics, Basingstoke-New York 2011, s. 19.

${ }^{29}$ Por. J. Barcz, Unia Europejska na rozstajach. Traktat z Lizbony. Dynamika i główne kierunki reformy ustrojowej, wyd. 3, Warszawa 2011, s. 34-41.

${ }^{30}$ F. Kinsky, Federalizm. Model ogólnoeuropejski, przeł. B. i M. Harasimowiczowie, Kraków 1999, s. 24, 50-58; W. Bokajło, Federalizm - rozwój idei i niektóre teorie, [w:] Federalizm. Teorie i koncepcje, red. W. Bokajło, Wrocław 1998, s. 140; P.J. Borkowski, Federalizm a budowanie jedności Europy, „Studia Europejskie” 2006, nr 2, s. 88-89. 
Problem rozumienia federalizmu pojawia się nie tylko na poziomie debaty naukowej i teoretycznej, ale również na poziomie politycznym. Także wśród państw członkowskich Unii Europejskiej istnieje brak zgody co do rozumienia pojęcia federacji europejskiej i tego, co niesie ze sobą zastosowanie zasady federalnej w praktyce. Francja i Wielka Brytania to, jak się wydaje, najwięksi przeciwnicy federalizowania Unii, które oznaczałoby dla nich gwałtowne ograniczenie zakresu posiadanej suwerenności i wysoki poziom centralizacji na poziomie unijnym. Niemcy, będąc państwem federalnym, pojmują federalizm jako gwarancję poszanowania praw części składowych federacji, ścisłego podziału kompetencji i przede wszystkim określonego stopnia decentralizacji. Najciekawszym i najbardziej jaskrawym przykładem tej odmienności w rozumieniu „federalnej Unii” jest okres negocjacji Traktatu z Maastricht. W preambule do traktatów rzymskich znalazła się deklaracja państw członkowskich, iż są zdecydowane „stworzyć podstawy coraz ściślejszego związku między narodami Europy" ${ }^{31}$. Na etapie negocjacji traktatu, który miał ustanowić unię polityczną między państwami członkowskimi, Prezydencja luksemburska zaproponowała, by w jego preambule zapowiedzieć „nowy etap procesu prowadzącego stopniowo do Unii z federalnym celem". Kanclerz Niemiec, Helmut Kohl, wskazywał w tym czasie, że „Europa bez struktur federacyjnych i zasady pomocniczości nie będzie mieć z pewnością żadnej przyszłości”. Premier Wielkiej Brytanii, John Major, oznajmił natomiast, że Wielka Brytania nie będzie tolerować jakichkolwiek odniesien do federalizmu. Stanowisko brytyjskie było jednak na tyle nieugięte, że pozostano przy „coraz ściślejszym związku między narodami Europy”. W debacie podkreślano wówczas, że ostatecznie przyjęte sformułowanie implikuje, iż w przyszłości możliwy jest dużo większy stopień centralizacji niż miałoby to miejsce w przypadku „federalnego celu”32. Co ciekawe, w liście do Przewodniczącego Rady Europejskiej, Donalda Tuska, przesłanym pod koniec 2014 r. w kontekście toczących się negocjacji w sprawie dalszego udziału Wielkiej Brytanii w projekcie integracyjnym, premier David Cameron napisał, iż pragnie „formalnie i nieodwracalnie” wyłączyć swój kraj z zobowiązania integracji w kierunku „coraz ściślejszej unii” ${ }^{33}$. Dla Wielkiej Brytanii także ta formuła okazała się być zbyt daleko idąca i zagrażająca jej suwerenności.

31 „Déterminés à établir les fondements d'une union sans cesse plus étroite entre les peuples européens”; „Determined to lay the foundations of an ever closer union among the peoples of Europe".

32 M. Burgess, Federalism and European Union..., s. 206-207; P.J. Borkowski, Polityczne teorie..., s. 50; J. Węc, Spór o kształt ustrojowy Wspólnot Europejskich I Unii Europejskiej w latach 1950-2010. Między idea ponadnarodowości a współpraca międzyrządowa. Analiza politologiczna, wyd. 2 rozszerzone, Kraków 2012, s. 202.

33 Prime Minister David Cameron letter to President of the European Council Donald Tusk "A New Settlement for The United Kingdom in a Reformed European Union", 10.11.2014, https:// www.gov.uk/government/uploads/system/uploads/attachment_data/file/475679/Donald_Tusk_ letter.pdf, s. 3 (dostęp: 17 stycznia 2016). 
Kilkakrotnie wspomniany został projekt Jeana Monneta zakładający stopniowe pogłębianie integracji europejskiej, która w ostatecznie miałaby ukonstytuować europejską federację. W tym kontekście warto zastanowić się przez chwilę, czy w obecnym stanie rozwoju Unii Europejskiej faktycznie doszło do zbliżenia w tym kierunku. Podobnie jak w przypadku próby zdefiniowania założeń federalizmu i pytania o to, czym jest federacja, tak i w tym przypadku brak jednoznacznej odpowiedzi. Michael Burgess jako federalne elementy Unii Europejskiej wskazuje bezpośrednie wybory do Parlamentu Europejskiego, metodę głosowania większościowego, jurysdykcję TSUE, ustanowienie Komisji Europejskiej — wykonawczej instytucji niezależnej w swoich działaniach od państw członkowskich i odpowiedzialnej przed Parlamentem Europejskim ${ }^{34}$. Paweł Borkowski podkreśla znaczenie systemu prawa unijnego, $w$ tym zasady pierwszeństwa prawa unijnego przed krajowym, instytucji ponadnarodowych, wspólnej waluty oraz obywatelstwa europejskiego ${ }^{35}$. Tanja A. Börzel i Thomas Risse, reprezentanci niemieckiej szkoły myślenia o federalizmie, wskazują, iż federalność Unii Europejskiej objawia się poprzez: 1) system rządów oparty na co najmniej dwóch poziomach rządzenia, z których każdy podlega własnym prawom oraz bezpośrednio wpływa na jednostki; 2) traktaty europejskie, które rozdzielają kompetencje i zasoby pomiędzy te poziomy; 3) istniejące klauzule określające obszary wspólnego rządzenia, w których nakładają się na siebie kompetencje tych poziomów; 4) prawo unijne („federacyjne") posiadające pierwszeństwo nad prawem krajowym; 5) unijne prawo coraz częściej jest tworzone na podstawie decyzji podejmowanych większością głosów, zobowiązując do jego przestrzegania państwa temu prawu przeciwne; 6) ustrój i procedury działania instytucji unijnych gwarantujących reprezentację poglądów „mniejszości”; 7) Trybunał Sprawiedliwości Unii Europejskiej pełniący rolę arbitra przy rozstrzyganiu sporów między państwami członkowskimi i instytucjami unijnymi; 8) Parlament Europejski wybierany jest w wyborach bezpośrednich ${ }^{36}$.

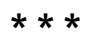

Osobną kwestią, wymagającą dalszych badań mieszczących się poza ramami niniejszego artykułu, jest sprawa czynników, które mogą sprzyjać postępującej federalizacji Unii Europejskiej lub też ten proces hamować. Jednoznaczna ocena utopijności bądź realności projektów federalnych w dużej mierze zależy właśnie od wyników tych badań. Jak się wydaje, w dotychczasowej debacie bliższe utopii okazały się być koncepcje klasycznego federalizmu rewolucyjnego, wzywające do zerwania z państwem narodowym i połączenia narodów europejskich w federację.

${ }^{34}$ M. Burgess, Federalism, s. 40.

${ }_{35}$ P.J. Borkowski, Polityczne teorie..., s. 64.

${ }^{36}$ T.A. Börzel, T. Risse, Who is Afraid of a European Federation? How to Constitutionalise a Multi-Level Governance System, [w:] What Kind of Constitution for What Kind of Polity?..., s. 53. 
Kontrpropozycja - federalizm ewolucyjny utożsamiany z myślą Jeana Monneta - okazał się być o wiele skuteczniejszy. Ironią losu pozostaje fakt, że projekt Spinellego z 1984 r. został wprowadzony w życie właśnie tzw. metodą Monneta $^{37}$. Paolo Ponzano wskazuje, iż około $2 / 3$ „Projektu Spinellego” zostało wdrożone w Jednolitym Akcie Europejskim, Traktacie z Maastricht, Traktacie z Amsterdamu i Traktacie $z$ Nicei. Z pozostałej $1 / 3$ przeszło połowa została uwzględniona w Traktacie z Lizbony ${ }^{38}$. Co ciekawe, J. Monnet nie przewidział, że w roli głównego „federatora” wystąpi Trybunał Sprawiedliwości Unii Europejskiej, który w kilku znaczących orzeczeniach ustanowił najważniejsze zasady prawa unijnego ${ }^{39}$, uznawane za główne elementy federalne w konstrukcji integracyjnej. W tym kontekście można postawić hipotezę, iż współczesne koncepcje mają zdecydowanie większe szanse powodzenia - po pierwsze wypracowane są w oparciu o pewne realia procesów integracyjnych w Europie, po drugie wybrały już sprawdzoną metodę federalizowania Unii w oparciu o stopniowe reformy.

Utopijne jest niewątpliwie stworzenie państwa federalnego, nie ma bowiem zgody na przekształcenie UE w państwo, ale jak zostało powiedziane - ambicją federalistów było stworzenie zupełnie nowej formuły, a nie powielanie już istniejących w rzeczywistości wzorców. Pojawiła się w efekcie potrzeba zdefiniowania nowego bytu — federacji europejskiej. Unia Europejska jest „specjalistką” od tworów sui generis, a więc i w tym przypadku nie będzie to nic dziwnego. Dowodzi tego przede wszystkim stopień, w jakim federalne koncepcje integracji europejskiej już zostały zastosowane w praktyce, czego przejawem jest znacząca ilość federalnych elementów konstrukcji europejskiej. W efekcie nie można się oprzeć wrażeniu, że federacja europejska częściowo została już wprowadzona „tylnymi drzwiami”.

${ }^{37}$ Na większą skuteczność „metody Monneta” wskazuje Michael Burgess, podkreślając równocześnie, że wiele z postulatów Spinellego zostało zrealizowanych od czasów przyjęcia Jednolitego Aktu Europejskiego. M. Burgess, Federalism, s. 33.

${ }^{38}$ P. Ponzano, The "Spinelli Treaty" of February 1984: The Start of the Process of Constitutionalizing the EU, [w:] EU Federalism and Constitutionalism. The Legacy of Altiero Spinelli, red. A. Glencross, A.H. Trechsel, Lanham 2010, s. 10.

${ }^{39}$ Chodzi tu przede wszystkim o orzeczenia Van Gend ఓ Loos, ustanawiające zasadę skutku bezpośredniego prawa wspólnotowego (unijnego), Costa v. Enel, ustanawiające zasadę pierwszeństwa prawa wspólnotowego (unijnego) przed krajowym. W orzeczeniu Van Gend \& Loos podkreślono również, że prawo tworzone na poziomie wspólnotowym (unijnym) oddziałuje bezpośrednio na obywateli państw członkowskich. Było to pierwsze z licznych orzeczeń TS ustanawiających i rozszerzających uprawnienia jednostek, co stanowiło podstawę do stworzenia instytucji obywatelstwa Unii Europejskiej. Wyrok Trybunału Sprawiedliwości z dnia 5 lutego 1963 r. w sprawie 26/62, http://curia. europa.eu/arrets/TRA-DOC-PL-ARRET-C-0026-1962-200406974-05_00.html (dostęp: 17 stycznia 2016); Wyrok Trybunału Sprawiedliwości z dnia 15 lipca 1964 r. w sprawie C-6/64, http://curia.europa. eu/arrets/TRA-DOC-PL-ARRET-C-0006-1964-200406979-05_00.html (dostęp: 17 stycznia 2016); R. Grzeszczak, Dwie narracje o obywatelstwie unijnym - obywatel rynku i obywatel unii europejskiej, [w:] Wspólczesne koncepcje ochrony wolności i praw podstawowych, red. A. Bator, M. Jabłoński, M. Maciejewski, K. Wójtowicz, Wrocław 2015, (dostęp internetowy przez Bibliotekę Cyfrową Uniwersytetu Wrocławskiego); A. Gubrynowicz, Obywatelstwo europejskie - stan obecny i perspektywy, [w:] „Zeszyty OIDE” nr 9: Obywatelstwo Unii Europejskiej, Warszawa 2008, s. 7. 
Oczywiście należy podkreślić, że niezbędna jest analiza znaczenia tych elementów dla funkcjonowania całego projektu europejskiego, a więc pytanie, jak istotny jest wpływ tych elementów, chociażby na procesy decyzyjne.

Na marginesie można zauważyć, że federaliści etapu klasycznego zasadniczo mieli rację w jednej sprawie - integracja okazała się kluczem do sukcesu, którym jest trwający od ponad 50 lat pokój, a przy sile politycznych, gospodarczych i społecznych powiązań w Unii Europejskiej wybuch europejskiego konfliktu już nie wydaje się możliwy.

\section{Bibliografia}

Barcz J., Unia Europejska na rozstajach. Traktat z Lizbony. Dynamika i główne kierunki reformy ustrojowej, wyd. 2, Warszawa 2010.

Barroso J.M., Przewodniczący Komisji Europejskiej, Orędzie o stanie Unii w 2012 r., Sesja plenarna Parlamentu Europejskiego, Strasburg 12 września 2012 r., http://europa.eu/rapid/press-release_SPEECH-12-596_pl.htm.

Bonucci M., Italian PM vows to push for United States of Europe during presidency, EurActiv.com 09.05.2014, http://www.euractiv.com/sections/eu-elections-2014/italian-pm-vows-push-united-states-europe-during-presidency-302048.

Borkowski P.J., Federalizm a budowanie jedności Europy, „Studia Europejskie” 2006, nr 2.

Borkowski P.J., Polityczne teorie integracji międzynarodowej, Warszawa 2007.

Burgess M., Federalism and European Union: The Building of Europe, 1950-2000, London-New York 2000.

Cichocki M.A., Zapomniana Europa, „Teologia Polityczna” 2006/2007, nr 4.

Coudenhove-Kalergi R., Pan-Europa, Racibórz 2005.

Duff A., Federacja już!, przeł. W. Piecyk, Warszawa 2011.

EU Federalism and Constitutionalism. The Legacy of Altiero Spinelli, red. A. Glencross, A.H. Trechsel, Lanham 2010.

European Integration Theory, red. A. Wiener, T. Diez, wyd. 2, New York-Oxford 2009.

Federalizm. Teorie i koncepcje, red. W. Bokajło, Wrocław 1998.

Gubrynowicz A., Obywatelstwo europejskie - stan obecny i perspektywy, [w:] „Zeszyty OIDE” nr 9: Obywatelstwo Unii Europejskiej, Warszawa 2008.

Jaskulski A., Federalizm europejski początków integracji europejskiej i doby kryzysu, „Rocznik Integracji Europejskiej" 2012, nr 6.

Kinsky F., Federalizm. Model ogólnoeuropejski, Kraków 1999.

McCormick J., European Union Politics, Basingstoke-New York 2011.

Oficjalna strona internetowa The Spinelli Group, http://www.spinelligroup.eu.

Oficjalna strona internetowa The State of the Union, https://stateoftheunion.eui.eu/.

Parzymies S., Między Europa ojczyzn a federacja: fałszywy dylemat europejskiej integracji, wystąpienie na Pierwszym Sympozjum im. Ministra Krzysztofa Skubiszewskiego poświęcone polityce zagranicznej RP, zorganizowanym przez Instytut Stosunków Międzynarodowych Uniwersytetu Warszawskiego oraz przez Fundację imienia Krzysztofa Skubiszewskiego, Uniwersytet Warszawski, 21 lutego 2012 r.

Polska w procesie integracji europejskiej. Dekada doświadczeń (2004-2014), red. K.A. Wojtaszczyk, M. Mizerska-Wrotkowska, W. Jakubowski, Warszawa 2014.

Prime Minister David Cameron letter to President of the European Council Donald Tusk "A New Settlement for The United Kingdom in a Reformed European Union", 10 November 2014, 
https://www.gov.uk/government/uploads/system/uploads/attachment_data/file/475679/Donald_Tusk_letter.pdf.

Przemówienie Ministra Radosława Sikorskiego „Polska i przyszłość Unii Europejskiej”” na forum Niemieckiego Towarzystwa Polityki Zagranicznej, Berlin, 28 listopada 2011 r., https://www. msz.gov.pl/resource/c2a33d88-7b8d-4fa5-8680-a67a4b2b38af:JCR.

Schäuble W., Lamers K., Überlegungen zur europäischen Politik, 1.9.1994, oficjalna strona internetowa CDU/CSU, https://www.cducsu.de/upload/schaeublelamers94.pdf.

The Spinelli Group, Bertelsmann Stiftung, A Fundamental Law of the European Union, Gütersloh 2013.

Węc J., Spór o kształt ustrojowy Wspólnot Europejskich I Unii Europejskiej w latach 1950-2010. Między idea ponadnarodowości a wspótpraca międzyrządowa. Analiza politologiczna, wyd. 2, rozszerzone, Kraków 2012.

What Kind of Constitution for What Kind of Polity? Response to Joschka Fischer, red. Ch. Joerges, Y. Mény, J.H.H. Weiler, The Robert Schuman Centre for Advaced Studies at the European University Institute - Harvard Law School, Florence-Cambridge 2000.

Wspótczesne koncepcje ochrony wolności i praw podstawowych, red. A. Bator, M. Jabłoński, M. Maciejewski, K. Wójtowicz, Wrocław 2015, (dostęp internetowy przez Bibliotekę Cyfrową Uniwersytetu Wrocławskiego).

Wyrok Trybunału Sprawiedliwości z dnia 5 lutego 1963 r. w sprawie 26/62, http://curia.europa.eu/ arrets/TRA-DOC-PL-ARRET-C-0026-1962-200406974-05_00.html.

Wyrok Trybunału Sprawiedliwości z dnia 15 lipca 1964 r. w sprawie C-6/64, http://curia.europa.eu/ arrets/TRA-DOC-PL-ARRET-C-0006-1964-200406979-05_00.html. 